\title{
Analisis Manajemen Risiko Sistem Informasi Pengelolaan Data English Proficiency Test (EPT) dan Portal Informasi di UPT Bahasa Universitas Lampung Menggunakan Metode ISO 31000
}

\author{
${ }^{1}$ Monica, ${ }^{2}$ Didik Kurniawan \& ${ }^{3}$ Rizky Prabowo \\ 1,2,3 Jurusan Ilmu Komputer FMIPA Universitas Lampung \\ Jalan Prof. Sumantri Brojonegoro No. 1 Bandar Lampung 35145 \\ ${ }^{1}$ monicamonik77@gmail.com, 2didikunila@gmail.com, ${ }^{3}$ rizky.prabowo@fmipa.unila.ac.id,
}

\begin{abstract}
UPT Language University of Lampung (Unila) is one of the Technical Services Unit (UPT) that utilizes information systems to support effectiveness and efficiency in its implementation in the field. The purpose of this study is to analyze the process of information system risk management at the Unila Language UPT using ISO 31000 and produce recommendations for work units about effective control measures and appropriate treatment for the risks faced. Information system risk management at UPT Language Unila is implemented to anticipate the source of risk threats by means of communication and consultation, setting the context (scope), risk assessment, monitoring and review, and handling. The results of this risk management research are, there are 15 possible risks. These risks are classified into 3 risk categories including personnel risk, system and infrastructure risks, and incidental risks. The level of risk is divided into 5 namely, very high risk, high risk, moderate risk, low risk, and very low risk.
\end{abstract}

Keywords: Risk Management, Information Systems, ISO 31000, UPT Language Unila

\section{Pendahuluan}

UPT Bahasa Universitas Lampung (Unila) merupakan salah satu Unit Pelayanan Teknis (UPT) yang membantu universitas dalam mengimplementasikan program dan kegiatan yang menunjang pembelajaran dan layanan kebahasaan. Dalam meningkatkan pelayanannya, UPT Bahasa memanfaatkan sistem informasi yang dapat menunjang efektifitas dan efisiensi dalam pengimplementasiannya dilapangan.

Dalam pengimplementasiannya, terdapat risiko yang ditimbulkan pada tahapan-tahapan proses bisnisnya. Penggunaan sistem informasi harus diiringi dengan pengelolaan informasi yang tepat dan sesuai sehingga dapat meminimalisir risiko-risiko yang mungkin terjadi didalam proses bisnisnya.

Proses menganalisa serta memperkirakan timbulnya suatu risiko dalam suatu kegiatan disebut sebagai manajemen risiko [1]. Dengan adanya manajemen risiko dapat mengetahui risiko apa yang dapat merugikan bagi pihak UPT maupun pengguna.

Dalam penelitian ini dapat menggunakan metode ISO 31000. Standar ISO 31000 memiliki perspektif yang jauh lebih luas yaitu dapat diterapkan dalam berbagai lingkup maupun kegiatan, dan lebih konseptual dibandingkan dengan standar lainnya [2]. Untuk mengetahui proses penerapan manajemen risiko sistem informasi UPT Bahasa tersebut, diperlukan penelitian tentang sejauh mana penerapan manajemen risiko sistem informasi UPT Bahasa dalam menilai sumber 
ancaman dan kerentanan, menganalisis, mengurangi, serta mengevaluasi risiko terhadap aset informasi UPT Bahasa di Unila.

\section{Proses Manajemen Risiko}

Proses manajemen risiko menggunakan metode ISO 31000 meliputi identifikasi risiko, analisis risiko dan evaluasi risiko.

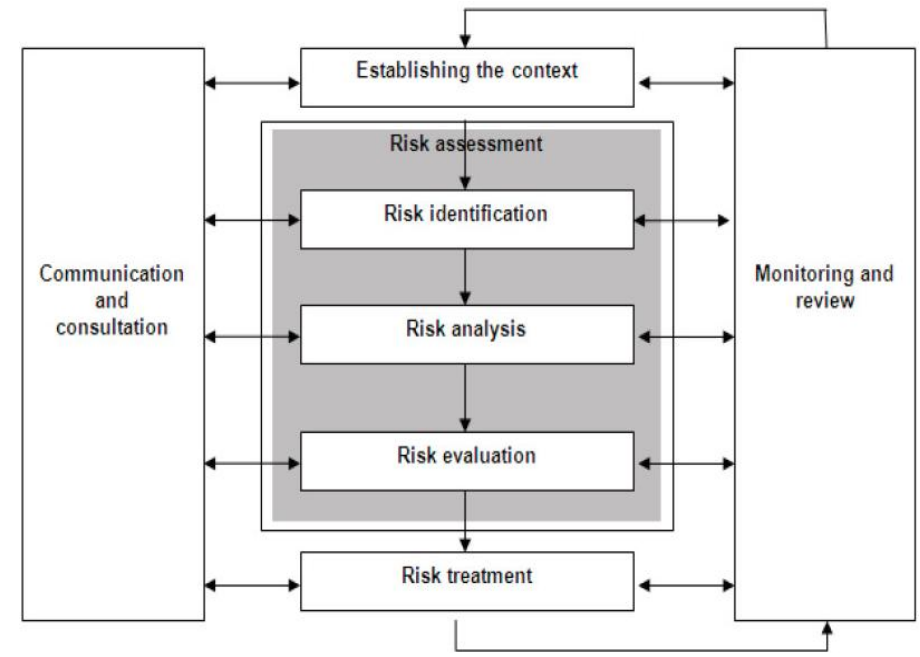

Gambar 1. Proses Manajemen Risiko [3]

Adapun tahap yang dilakukan yaitu:

\section{a. Identifikasi Risiko}

Tahapan identifikasi risiko adalah sebagai berikut:

1. Identifikasi risiko sistem yaitu dengan mengumpulkan data mengenai perangkat keras, perangkat lunak, keamanan sistem, dan fungsi dari sistem. Hal ini dilakukan untuk mengetahui batasan-batasan apa saja pada sistem informasi di UPT Bahasa.

2. Identifikasi risiko personil yaitu dengan mengumpulkan data mengenai ancaman sumber risiko pada sistem serta bentuk ancaman dari setiap sumber risiko tersebut yang berasal dari tindak kejahatan yang diakibatkan oleh manusia.

3. Identifikasi risiko insidental yaitu dengan mengumpulkan data mengenai risiko-risiko apa saja yang diakibatkan oleh faktor alam atau lingkungan yang dapat menghabat jalannya kegiatan di UPT Bahasa.

b. Analisis Risiko

Tahapan analisis risiko adalah sebagai berikut:

1. Menentukan status risiko untuk mendapatkan peringkat likehood yang mengindikasikan probabilitas bahwa sumber ancaman berpotensi dapat melakukan ancaman.

2. Analisis dampak yaitu dengan menentukan dampak buruk yang diakibatkan sebuah ancaman yang berhasil dilakukan.

\section{c. Evaluasi Risiko}


Tahapan evaluasi resiko adalah dengan menentukan risiko dinilai dari pengumpulan data pada tahap sebelumnya seperti likehood serta dampak yang dihasilkan dari setiap risiko. Sehingga pada tahap ini akan menghasilkan peringkat risiko yang terjadi pada sistem informasi di UPT Bahasa.

\section{Pembahasan}

\section{a. Identifikasi}

Berdasarkan hasil observasi dan wawancara pada pihak UPT Bahasa, terdapat 15 kemungkinan terjadinya risiko. Risiko tersebut digolongkan menjadi 3 kategori risiko antara lain risiko personil, risiko sistem dan infrastruktur, dan risiko insidental.

\section{b. Analisis Risiko}

Analisis risiko pada penelitian ini dilakukan dengan cara memberikan kuisioner kepada pihak UPT Bahasa untuk mengetahui besaran kemungkinan terjadinya risiko dan dampak yang ditimbulkan akibat risiko tersebut. Formula untuk menghitung status risiko adalah: Level Risiko $=$ Probabilitas x Dampak.

\section{c. Evaluasi Risiko}

Proses evaluasi risiko akan menentukan risiko-risiko mana yang memerlukan perlakuan dan bagaimana prioritas perlakuan atas risiko-risiko tersebut. Untuk menentukan peringkat risiko, diperlukan matriks yang berisi kombinasi kemungkinan dan dampak. Berikut ini adalah tabel peta risiko sistem CAT-EPT dan portal informasi yang dapat dilihat pada Gambar 2 di bawah ini:

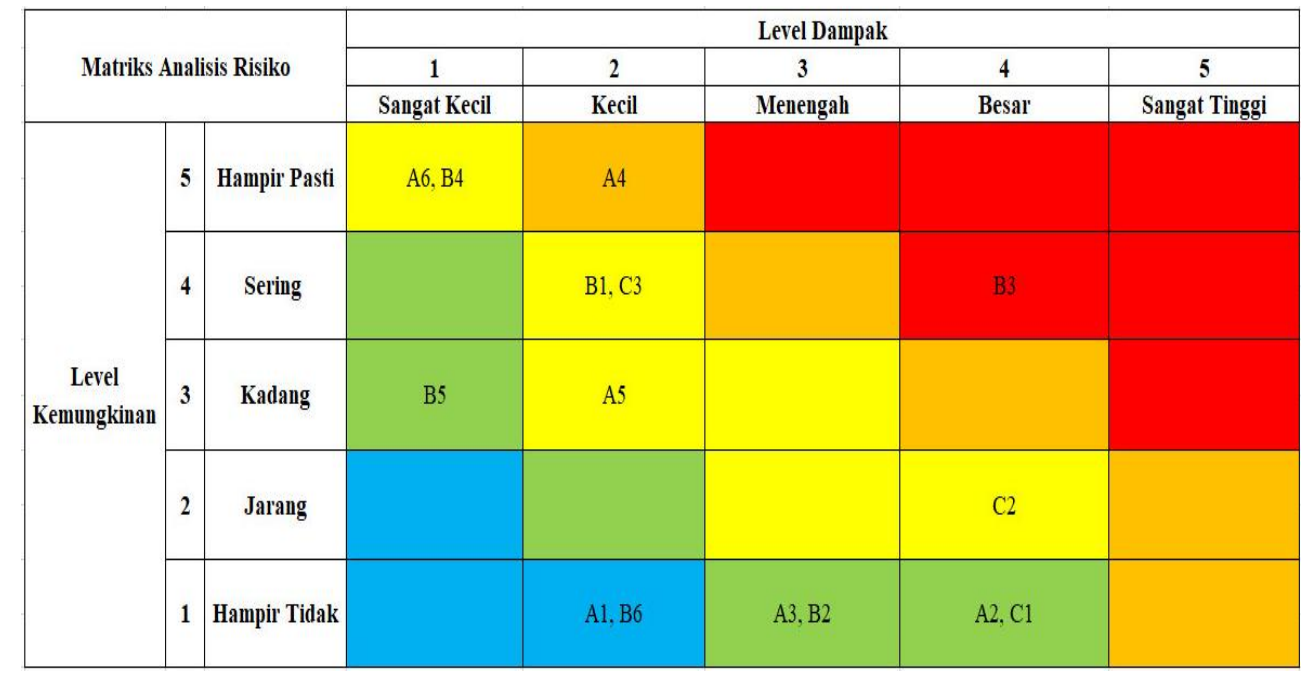

Gambar 2. Peta Risiko

Menetapkan level risiko yaitu batasan besaran kuantitatif level kemungkinan terjadinya risiko dan level dampak risiko yang dapat diterima, sebagaimana dituangkan pada kriteria risiko. Level sangat tinggi (5) disimbolkan dengan warna merah, level tinggi (4) disimbolkan dengan warna orange, level sedang (3) disimbolkan dengan warna kuning, level rendah (2) disimbolkan dengan warna hijau, dan level sangat rendah (1) disimbolkan dengan warna biru. Berikut ini merupakan tabel level risiko yang dapat di lihat pada Tabel 1 di bawah ini: 
Tabel 1. Level Risiko

\begin{tabular}{lll}
\hline Level Risiko & Besaran & Simbol \\
\hline Sangat Tinggi (5) & 15 & \\
\hline Tinggi (4) & 10 \\
\hline Sedang (3) & 5 \\
\hline Rendah (2) & 3 \\
\hline Sangat Rendah (1) & 1 \\
\hline
\end{tabular}

\section{d. Rekomendasi Penanganan}

Perlakuan risiko meliputi upaya untuk menyeleksi pilihan-pilihan yang dapat mengurangi atau meniadakan dampak serta kemungkinan terjadinya risiko. Perlakuan terhadap suatu risiko dapat berupa salah satu dari empat perlakuan sebagai berikut:

1. Menghindari risiko (risk avoidance): dengan melakukan penanganan risiko dengan mengubah atau menghilangkan sasaran atau kegiatan untuk menghilangkan risiko tersebut.

2. Mengalihkan risiko (risk sharing/risk transfer): manajemen mengelola risiko lain dengan bersekutu dengan pihak lain melalui joint venture dan joint financing dalam rangka menanggung risiko tersebut bersama-sama.

3. Mengurangi atau mitigasi (mitigation): melakukan perlakuan risiko untuk mengurangi kemungkinan timbulnya risiko, atau mengurangi dampak risiko bila terjadi, atau mengurangi keduanya. Mengelola risiko dengan membuat prosedur dan pengawasan internal, pelatihan atau sosialisasi internal.

4. Menerima risiko (risk acceptance): manajemen menerima risiko tersebut sebagaimana adanya karena ada ketentuan seperti: sudah diamanatkan oleh undang-undang atau karena faktor alam.

Berikut ini adalah tabel identifikasi, analisis, evaluasi dan penanganan risiko yang dapat dilihat pada Tabel 1 di bawah ini:

Tabel 2. Identifikasi, Analisis, Evaluasi dan Rekomendasi Penanganan risiko

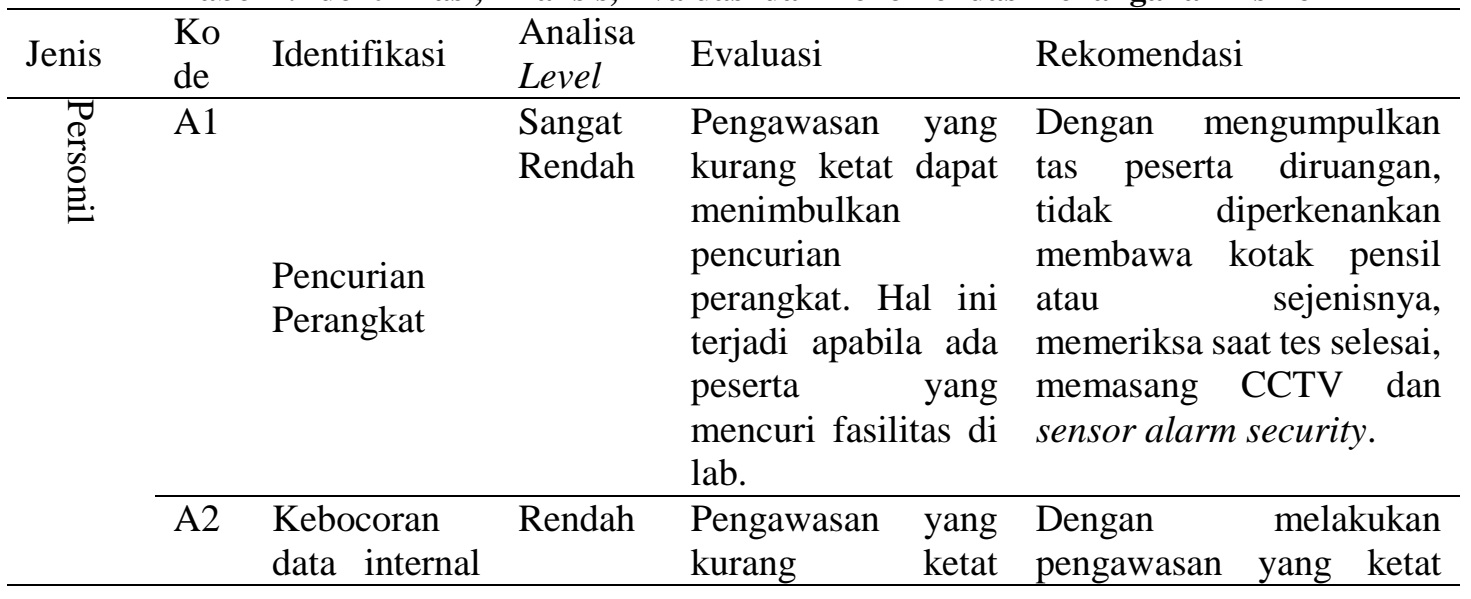




\begin{tabular}{|c|c|c|c|c|c|}
\hline Jenis & $\begin{array}{l}\text { Ko } \\
\text { de }\end{array}$ & Identifikasi & $\begin{array}{l}\text { Analisa } \\
\text { Level }\end{array}$ & Evaluasi & Rekomendasi \\
\hline & & $\begin{array}{l}\text { UPT Bahasa } \\
\text { (soal) }\end{array}$ & & $\begin{array}{l}\text { terhadap peserta tes } \\
\text { dapat menimbulkan } \\
\text { kebocoran soal. Hal } \\
\text { itu bisa terjadi } \\
\text { apabila peserta } \\
\text { mengambil gambar } \\
\text { atau merekam soal- } \\
\text { soal saat tes } \\
\text { menggunakan } \\
\text { handphone. }\end{array}$ & $\begin{array}{l}\text { saat tes. Seperti melarang } \\
\text { membawa handphone, } \\
\text { kamera dan alat perekam } \\
\text { lainnya saat melakukan } \\
\text { tes, dan memantau } \\
\text { pelaksaan tes pada CCTV. }\end{array}$ \\
\hline & A3 & $\begin{array}{l}\text { Kelalaian } \\
\text { dalam } \\
\text { memasukan } \\
\text { data (ada 1-2 } \\
\text { soal yang } \\
\text { salah) }\end{array}$ & Rendah & $\begin{array}{lr}\text { Saat menginput } \\
\text { bank soal, sering } \\
\text { terjadi kesalahan } \\
\text { penulisan dalam } \\
\text { soal. }\end{array}$ & $\begin{array}{l}\text { Dengan memeriksa } \\
\text { kembali pada saat bank } \\
\text { soal di input atau dengan } \\
\text { membuat SOP peng-input- } \\
\text { an bank soal. Mencatat } \\
\text { soal yang salah dan soal } \\
\text { yang salah dihitung bonus } \\
\text { pada saat pengelolaan } \\
\text { data, supaya tidak } \\
\text { merugikan peserta yang } \\
\text { tes. }\end{array}$ \\
\hline & A4 & $\begin{array}{l}\text { Penyalahgun } \\
\text { aan hak } \\
\text { akses/User } \\
\text { ID (peserta) }\end{array}$ & Tinggi & $\begin{array}{lr}\text { Sering } & \text { terjadi } \\
\text { kecurangan } & \text { yang } \\
\text { dilakukan } & \text { oleh } \\
\text { peserta } & \text { saat } \\
\text { melakukan } & \text { tes, } \\
\text { yaitu } & \text { dengan } \\
\text { menggunakan joki } \\
\text { saat melaksanakan } \\
\text { tes. }\end{array}$ & $\begin{array}{l}\text { Dengan memasang sistem } \\
\text { pengenalan wajah untuk } \\
\text { mengidentifikasi peserta } \\
\text { tes. }\end{array}$ \\
\hline & A5 & $\begin{array}{l}\text { Human error } \\
\text { (nilai) }\end{array}$ & Sedang & $\begin{array}{l}\text { Kesalahan dalam } \\
\text { menampilkan hasil } \\
\text { nilai. }\end{array}$ & $\begin{array}{l}\text { Melakukan pelatihan pada } \\
\text { pegawai, membuat } \\
\text { pembatasan hak akses } \\
\text { sesuai dengan tingkat } \\
\text { kepentingannya, } \\
\text { melakukan pengawasan } \\
\text { secara internal terhadap } \\
\text { apa yang dikerjakan. }\end{array}$ \\
\hline & A6 & Data double & Sedang & $\begin{array}{lr}\text { Peserta } & \text { bisa } \\
\text { mendaftar beberapa } \\
\text { kali dalam satu } \\
\text { waktu dan tidak } \\
\text { bisa dihapus. }\end{array}$ & $\begin{array}{lr}\text { Dengan } & \text { melakukan } \\
\text { perbaikan } & \text { terhadap } \\
\text { kekurangan } & \text { sistem } \\
\text { informasi seperti peserta } & \text { prak } \\
\text { tidak bisa tidak mendaftar } \\
\text { sebelum proses verikasi } \\
\text { selesai. }\end{array}$ \\
\hline 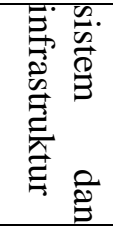 & B1 & $\begin{array}{l}\text { Vandalism } \\
\text { (merusak } \\
\text { fasilitas } \\
\text { seperti meja, } \\
\text { kursi, dan }\end{array}$ & Rendah & $\begin{array}{l}\text { Menulis-nulis pada } \\
\text { meja dengan pena. }\end{array}$ & $\begin{array}{l}\text { Dengan memberi } \\
\text { peringatan kepada peserta } \\
\text { sebelum tes dimulai untuk } \\
\text { tidak merusak dan } \\
\text { menjaga fasilitas yang }\end{array}$ \\
\hline
\end{tabular}




\begin{tabular}{|c|c|c|c|c|c|}
\hline Jenis & $\begin{array}{l}\text { Ko } \\
\text { de }\end{array}$ & Identifikasi & $\begin{array}{l}\text { Analisa } \\
\text { Level }\end{array}$ & Evaluasi & Rekomendasi \\
\hline & & $\begin{array}{l}\text { perangkat } \\
\text { komputer) }\end{array}$ & & & $\begin{array}{l}\text { diberikan sebelum tes } \\
\text { dimulai. Memberi sanksi } \\
\text { kepada peserta yang } \\
\text { merusak fasilitas seperti, } \\
\text { membersihkan bekas } \\
\text { coretan, dan mengganti } \\
\text { fasilitas yang dirusak. }\end{array}$ \\
\hline & B2 & Over heat & Rendah & $\begin{array}{lr}\text { Terlalu lama } \\
\text { digunakan sehingga } \\
\text { membuat perangkat } \\
\text { keras r menjadi } \\
\text { panas. }\end{array}$ & $\begin{array}{l}\text { Dengan memasang } \\
\text { pendingin, arus listrik } \\
\text { stabil, ruangan bersuhu } \\
\text { normal. }\end{array}$ \\
\hline & B3 & $\begin{array}{l}\text { Koneksi } \\
\text { yang tiba- } \\
\text { tiba offline }\end{array}$ & $\begin{array}{l}\text { Sangat } \\
\text { Tinggi }\end{array}$ & $\begin{array}{lr}\text { Terjadi } & \text { karena } \\
\text { adanya } & \text { gangguan } \\
\text { jaringan } & \text { seperti } \\
\text { server } & \text { down, } \\
\text { jaringan terputus, } \\
\text { mati lampu, dan } \\
\text { lain-lain. }\end{array}$ & $\begin{array}{l}\text { Melaporkan permasalahan } \\
\text { ke pihak UPT TIK sesuai } \\
\text { dengan SOP. } \\
\text { Menyediakan server } \\
\text { cadangan yang diletakkan } \\
\text { di UPT Bahasa, program } \\
\text { aplikasi diinstal pada } \\
\text { server LAN yang } \\
\text { terdistribusi ke setiap } \\
\text { client (tidak terkoneksi ke } \\
\text { server pusat). }\end{array}$ \\
\hline & B4 & Sistem error & Rendah & $\begin{array}{lr}\text { Over } & \text { load, } \\
\text { bandwith } & \text { terbatas, } \\
\text { kesalahan } & \text { coding, } \\
\text { virus, } & \text { atau } \\
\text { kesalahan } & \\
\text { konfigurasi. } & \\
\end{array}$ & $\begin{array}{l}\text { Dengan mengajukan } \\
\text { penambahan bandwidth, } \\
\text { melakukan pembaharuan } \\
\text { sistem, dan melakukan } \\
\text { update antivirus. }\end{array}$ \\
\hline & B5 & Over load & Rendah & $\begin{array}{l}\text { Terlalu banyak } \\
\text { yang ingin tes pada } \\
\text { momen tertentu } \\
\text { seperti: sebelum } \\
\text { pendaftaran wisuda, } \\
\text { pembukaan BUMN } \\
\text { dan lain-lain. } \\
\text { Jumlah PC yang } \\
\text { tersedia hanya 54. }\end{array}$ & $\begin{array}{l}\text { Dengan membagi kuota } \\
\text { pendaftar seperti: dalam } 1 \\
\text { minggu terdapat } 3 \text { sesi. } \\
\text { Jumlah fakultas di Unila } \\
\text { ada } 8 \text { dan jumlah jurusan } \\
\text { ada } 63 \text {, sehingga sesi } \\
\text { pertama } 3 \text { fakultas, sesi } \\
\text { kedua } 3 \text { fakultas, dan sesi } \\
\text { ketiga } 2 \text { fakultas. }\end{array}$ \\
\hline & B6 & $\begin{array}{l}\text { Over } \\
\text { capacity }\end{array}$ & $\begin{array}{l}\text { Sangat } \\
\text { Rendah }\end{array}$ & $\begin{array}{l}\text { Tipe data untuk id } \\
\text { pada jadwal } \\
\text { TINYINT. } \\
\text { Kapasitasnya } \\
\text { terlalu kecil. }\end{array}$ & $\begin{array}{l}\text { Melakukan modify pada } \\
\text { database, dengan } \\
\text { memperbaharui tipe data } \\
\text { yang sesuai yang dapat } \\
\text { menampung banyaknya } \\
\text { data yang masuk setiap } \\
\text { harinya. }\end{array}$ \\
\hline 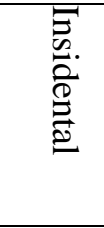 & $\mathrm{C} 1$ & Kebakaran & Rendah & $\begin{array}{lr}\text { Aliran } & \text { atau } \\
\text { ketengangan } & \text { listrik, } \\
\text { hubungan } & \text { arus } \\
\text { pendek } & \text { pada }\end{array}$ & $\begin{array}{l}\text { Dengan tidak melakukan } \\
\text { aktifitas yang dapat } \\
\text { memicu risiko tersebut. } \\
\text { Semua peralatan harus } \\
\text { dipastikan }\end{array}$ \\
\hline
\end{tabular}




\begin{tabular}{|c|c|c|c|c|c|}
\hline Jenis & $\begin{array}{l}\text { Ko } \\
\text { de }\end{array}$ & Identifikasi & $\begin{array}{l}\text { Analisa } \\
\text { Level }\end{array}$ & Evaluasi & Rekomendasi \\
\hline & & & & $\begin{array}{l}\text { peralatan elektronik } \\
\text { dan lain-lain. }\end{array}$ & $\begin{array}{l}\text { pemasangannnya dengan } \\
\text { benar dan perawatan } \\
\text { secara rutin. Pastikan } \\
\text { karyawan yang menangani } \\
\text { peralatan ini telah } \\
\text { menerima pelatihan yang } \\
\text { tepat, dan tersedia } \\
\text { instruksi yang jelas. Serta } \\
\text { menyediakan alat } \\
\text { pemadam kebakaran. }\end{array}$ \\
\hline & $\mathrm{C} 2$ & $\begin{array}{l}\text { Bencana } \\
\text { Alam }\end{array}$ & Sedang & $\begin{array}{l}\text { Peristiwa alam } \\
\text { seperti hujan, badai } \\
\text { dan petir. }\end{array}$ & $\begin{array}{l}\text { Menempatkan data center } \\
\text { pada tempat yang } \\
\text { strategis, artinya terbebas } \\
\text { dari ancaman bencana } \\
\text { alam seperti gempa, } \\
\text { banjir, dan petir. } \\
\text { Memasang pengaman anti } \\
\text { petir pada data center, alat } \\
\text { ini bisa mencegah } \\
\text { kerusakan pada data } \\
\text { center yang diakibatkan } \\
\text { oleh petir. }\end{array}$ \\
\hline & $\mathrm{C} 3$ & Mati Listrik & Sedang & $\begin{array}{l}\text { Pemadaman listrik } \\
\text { dalam waktu lebih } \\
\text { dari } 4 \text { jam atau } \\
\text { terjadi pada saat tes } \\
\text { berlangsung }\end{array}$ & $\begin{array}{l}\text { Dengan menyediakan } \\
\text { genset dan UPS } \\
\text { (Uninterruptible Power } \\
\text { Supply) sebagai alat back } \\
\text { up listrik ketika PC } \\
\text { kehilangan energi dari } \\
\text { sumber utamanya. }\end{array}$ \\
\hline
\end{tabular}

\section{Kesimpulan}

1. Dengan menggunakan ISO 31000 terlihat nilai risiko dengan lima tingkatan yaitu sangat redah, rendah, sedang, tinggi dan sangat tinggi.

2. Hasil dari identifikasi risiko didapat 15 sumber ancaman pada sistem informasi UPT Bahasa Universitas Lampung. Risiko tersebut digolongkan menjadi 3 kategori risiko yaitu risiko personil, risiko sistem dan infrastruktur, dan risiko insidental.

3. Hasil analisis dan evaluasi risiko terdapat 1 risiko yang bernilai sangat tinggi yaitu (koneksi tiba-tiba offline), 1 risiko yang bernilai tinggi yaitu (penyalahgunaan hak akses ), 4 risiko bernilai sedang yaitu (human error, data double, bencana alam, mati listrik), dan 7 risiko bernilai rendah yaitu (kebocoran data soal, kelalaian dalam memasukkan data, vandalism, overload, over heat, sistem error, kebakaran) dan 2 risiko yang bernilai sangat rendah yaitu (pencurian perangkat dan over capacity).

4. Penanganan risiko yang diterapkan berupa menghindari risiko (risk avoidance), mengalihkan risiko (risk sharing/risk transfer), mengurangi atau mitigasi (mitigation) dan menerima risiko (risk acceptance).

\section{DaftarPustaka}


[1] Susilo. (2017). Analisa Tingkat Resiko Tata Kelola Teknologi Informasi Perguruan Tinggi Menggunakan Model Framework National Institute of Standards \& Technology (NIST) Special Publication 800-30 dan IT General Control Questionnaire (ITGCQ). Journal Industrial Servicess Vol. 3c No. 1 Oktober 2017, 240.

[2] Susilo, L. J., dan Kaho, R. V. (2018). Manajemen Risiko Berbasis ISO 31000: untuk Industri Nonperbankan. Edisi Revisi. Jakarta: PPM.

[3] ISO. (2009). ISO 31000:2009 Risk Management - Principles and Guidelines. Switzerland: International Organization for Standarization. 